Open Access

\title{
A meta-analysis on the effect of implant characteristics on the survival of the wide-diameter implant
}

\author{
Miriam Ting ${ }^{1}$, Matthew Palermo ${ }^{1 *}$, David P. Donatelli ${ }^{1}$, John P. Gaughan ${ }^{2}$, Jon B. Suzuki ${ }^{1}$ and Steven R. Jefferies ${ }^{1}$
}

\begin{abstract}
The purposes of the study are to study the implant survival of the wide-diameter implant and to analyze if the length, the implant surface, or the placement location has any effect on its survival. Electronic databases were searched from inception to Dec 2014. Studies included in the review had implants placed in areas of adequate bone width and had clear inclusion and exclusion criteria for patient selection. Immediately placed and immediately loaded implants were excluded. A meta-analysis was done using the "random effects" model on the included studies. And, a meta-regression was used to evaluate the effects of location, length, and surface on the implant survival. Of the six studies selected, three evaluated surface-treated implants and three machined implants. The overall pooled survival rate of the wide implant is $96.3 \%$. The meta-regression showed that when using a wide implant, neither its surface nor its length nor its position in the maxilla or mandible adversely affected its survival $(P>0.05)$. This meta-analysis concluded that the location, length, and surface of the wide-diameter implant did not affect its survival and therefore suggested that when the conditions of the implant site corresponded to the inclusion criteria of our meta-analysis, choosing a wide-diameter implant in the posterior mandible or maxilla, where implant length may be limited by the nerve or the sinus, the use of a short implant regardless of its surface would not affect its survival.
\end{abstract}

Keywords: Wide-diameter implants, Surface-treated or machined implants, Short implants or long implants, Implants in the mandible or maxilla

\section{Review}

\section{Introduction}

Endosseous implants were used reliably in the treatment of various degrees of edentulism [1-7]. In restoring the edentulous ridge, the clinician could be faced with difficult bony situations. The wide-diameter implant could be used in these situations to improve primary stability by increasing the surface area available for osteointegration [8-10]. Biomechanically, the wide-diameter implant engaged maximal bone, increased initial stability, and improved stress distribution in the supporting bone [11]. In restoring a large molar, the wide implant has the added advantage of increasing the load bearing capacity and emergence profile of the final restoration [10]. It has been shown to be three to six times stronger than the

\footnotetext{
* Correspondence: palermom@temple.edu

'Kornberg School of Dentistry, Temple University, 3223 North Broad Street, Philadelphia, PA 19140, USA

Full list of author information is available at the end of the article
}

standard implant [12]. Wide-diameter implants were also used as rescue fixtures to replace fractured or nonintegrated implants [8]. Thus, the wide-diameter implants could become the implant of choice when faced with these challenging situations.

The aims of this review were to research the literature published till Dec. 15, 2014, on wide-diameter implants and to perform a meta-analysis to study (1) the widediameter implant survival of different lengths, (2) the wide-diameter implant survival of modified surface compared to machined surface, and (3) the implant survival of wide-diameter implants placed in the maxilla compared to the mandible.

\section{Materials and methods \\ Focused question}

1. Does length of the wide-diameter implant influence its survival?

\section{勿 Springer}


2. Does the surface modification influence its survival compared to machined implant surfaces?

3. Does the implant placement in the maxilla or the mandible influence its survival?

\section{Literature search and study design}

The database on PubMed, Web of Science, and Cochrane Central Register of Controlled Trials was searched from inception to December 15, 2014. The keywords for the search were "dental implants or dental implant" and "wide," and a reference librarian was consulted as to the most effective strategy. Gray literature was also searched on Google Scholar using advance search to find articles with all of the words "wide, dental, implants, endosseous, clinical, patients, survival" and without the words "animal, graft, augmentation, immediate, review". Hand searching was conducted on the reference lists of identified widediameter implant articles and was limited to articles not already identified in the above search strategy. Implant representatives of implant manufacturers were also contacted for any ongoing research pertaining to wide-diameter implants, and researchers were invited to clarify research information.

\section{Inclusion/exclusion criteria}

1. Randomized controlled trials, controlled clinical trials, cohort, and case series reporting on the implant survival of wide-diameter endosseous titanium implants with different surface modifications were included. Only prospective data were included. Case reports, conventional reviews, and systemic reviews were excluded.

2. Implant diameter greater or equal to $4.7 \mathrm{~mm}$ were considered wide-diameter implants.

3. Only articles with specific documentation for wide-diameter implants were included. This documentation includes implant length, location/ site, loading times, and specific failure data such as length, location, and timing of failure for wide-diameter implants.

4. Articles with information on implants placed in sites deemed to have adequate bone height and width, and did not require site development, were included. Articles with grafted sites and/or unclear description of how sites were selected were excluded.

5. Only articles with data on wide implants loaded after least 1-3 months of healing after implant placement were included; data on immediate placement in extraction sites and immediately loading implants were not covered in this review.

6. Wide-diameter implants used in immediate replacement of failed implants were excluded.
7. Studies with at least 1-year follow-up and included at least 10 implants regardless of diameter and length were included.

8. Patients with adequate health to undergo implant surgery and patients with controlled medical conditions were not excluded.

9. Smoking status of subjects was not considered a criterion for exclusion.

10.Non-English articles or articles without English translations were excluded due to language limitations.

\section{Screening and selection}

Two reviewers participated in selection of studies (MT and MP). At the initial phase of selection, abstracts and titles of articles were screened by one reviewer (MT) to exclude articles that clearly were not related to widediameter dental implants. The previously described inclusion and exclusion criteria were applied when including articles for full-text screening. When there was a doubt as to the relevance of the article, due to insufficient information in the abstract, the full-text article was analyzed together with a second reviewer (MP).

\section{Search results}

The search yielded 553 potentially relevant articles in PubMed, 303 in Web of Science, 35 in Cochrane Central Register of Controlled Trials, 64 from Google Scholar, and 19 not identified in the above search strategies from hand searching of reference lists of selected articles (Fig. 1). After screening the abstracts of the articles, 38 articles were selected for full-text screening from PubMed, 26 from Web of Science, 6 from Cochrane Central Register of Controlled Trials, 16 from Google Scholar, and 17 from hand searching of reference list. After elimination of duplicate articles, a total of 57 articles were selected for full-text screening.

Predetermined inclusion and exclusion criteria were applied to the selected full text by two reviewers (MT and MP); article selection was completed independently and then in unison. Areas of ambiguity were resolved through discussion. As for two articles that needed clarification of patient selection criteria, the authors were contacted via email and given 2 weeks to respond. One author responded with the requested information. Six articles remained for further review.

A total of 51 studies were excluded after the full-text review. These included 19 studies that did not document different lengths of wide implants studied, 15 studies that used graft materials in or around the implant sites, 4 studies that immediately placed implants in extraction sites or upon removal of failed implants, 2 studies that immediately loaded the implants, 10 studies that were 


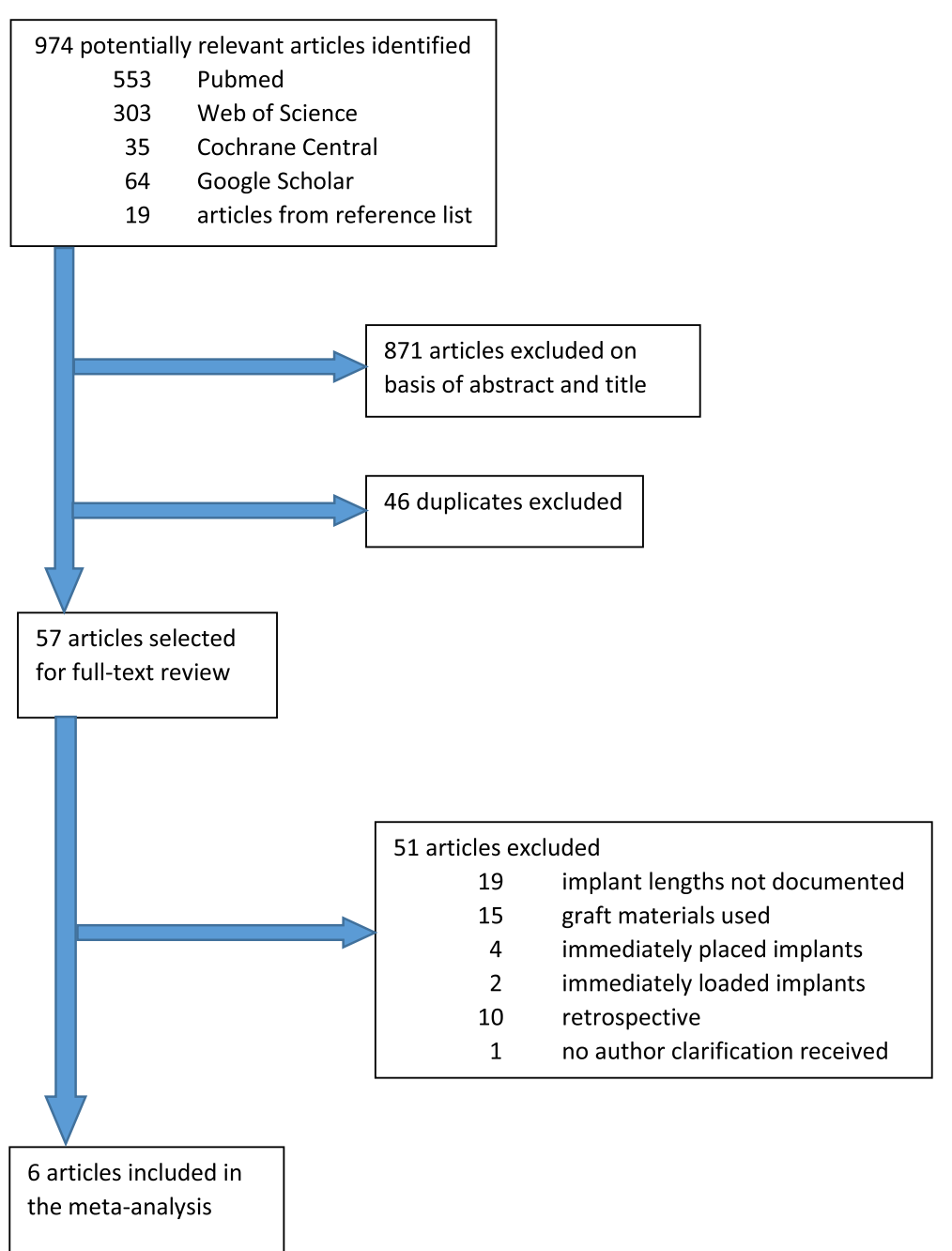

Fig. 1 Study selection for wide-diameter implant articles

Table 1 Wide-diameter implants

\begin{tabular}{|c|c|c|c|c|c|c|c|c|}
\hline $\begin{array}{l}\text { Implant diameter } \\
(\mathrm{mm})\end{array}$ & $\begin{array}{l}\text { Implant } \\
\text { lengths }\end{array}$ & $\begin{array}{l}\text { No. of implants } \\
\text { (total) }\end{array}$ & Implant type & $\begin{array}{l}\text { Implant } \\
\text { surface }\end{array}$ & $\begin{array}{l}\text { Prospective } \\
\text { clinical study }\end{array}$ & $\begin{array}{l}\text { Placement follow-up/ } \\
\text { mean (range) }\end{array}$ & $\begin{array}{l}\text { Implant survival } \\
(\%)\end{array}$ & $\begin{array}{l}\text { Age range } \\
\text { (years) }\end{array}$ \\
\hline 4.7 & $\begin{array}{l}8,10 \\
13,16\end{array}$ & 117 & $\begin{array}{l}\text { Zimmer (Screw } \\
\text { vent, Paragon) }\end{array}$ & $\begin{array}{l}\text { Acid-etched, } \\
\text { uncoated }\end{array}$ & $\begin{array}{l}\text { Khayat et al. } \\
2001 \text { [13] }\end{array}$ & $\begin{array}{l}\text { Healing } 3-6 \text { months } \\
\text { plus } 17 \text { months loading } \\
\text { (11-21 months) }\end{array}$ & 95 & - \\
\hline 5.0 & 7 & 14 & $\begin{array}{l}\text { Endopore } \\
\text { (Innova Corp) }\end{array}$ & $\begin{array}{l}\text { Sintered } \\
\text { porous }\end{array}$ & $\begin{array}{l}\text { Deporter et al. } \\
2001 \text { [18] }\end{array}$ & 32.6 months & 100 & $\begin{array}{l}25-76 \\
(53.7)\end{array}$ \\
\hline \multirow[t]{2}{*}{5.0} & $\begin{array}{l}8.5,10 \\
11.5\end{array}$ & 15 & $\begin{array}{l}\text { Mark III WP } \\
\text { (Nobel Biocare) }\end{array}$ & Ti-unite & $\begin{array}{l}\text { Schincaglia } \\
\text { et al. } 2008 \text { [17] }\end{array}$ & $\begin{array}{l}3-4 \text { months healing } \\
\text { plus }\end{array}$ & 100 & $\begin{array}{l}35-68 \\
(49.2)\end{array}$ \\
\hline & & & & & & 12 months loading & & \\
\hline 5.0 & 6 & 13 & $\begin{array}{l}\text { Brånemark } \\
\text { (Nobel Biocare) }\end{array}$ & Machined & $\begin{array}{l}\text { Friberg et al. } \\
2000 \text { [14] }\end{array}$ & 8 years ( $1-14$ years) & 100 & $38-93(63)$ \\
\hline 5.0 & $\begin{array}{l}6,7,8 \\
8.5,10\end{array}$ & 109 & $\begin{array}{l}\text { Brånemark } \\
\text { (Nobel Biocare) }\end{array}$ & Machined & $\begin{array}{l}\text { Tawil and } \\
\text { Younan } 2003 \\
\text { [15] }\end{array}$ & $\begin{array}{l}\text { Healing plus } \\
24 \text { months loading }\end{array}$ & 94.5 & $\begin{array}{l}22-80 \\
(53.6)\end{array}$ \\
\hline 5.0 & $\begin{array}{l}7,8.5 \\
10,11.5\end{array}$ & 38 & $\begin{array}{l}\text { Brånemark } \\
\text { (Nobel Biocare) }\end{array}$ & Machined & $\begin{array}{l}\text { Polizzi et al. } \\
2000 \text { [16] }\end{array}$ & 36 months & 92 & $29-69$ \\
\hline
\end{tabular}


Table 2 Wide surface-treated Implants

\begin{tabular}{|c|c|c|c|c|c|c|}
\hline Study & Implant surface & Implant type & Implant length & No. of implants & No. failed & $\%$ survived \\
\hline \multirow[t]{4}{*}{ Khayat et al. 2001 [13] } & \multirow[t]{4}{*}{ Acid-etched, uncoated } & \multirow[t]{4}{*}{ Zimmer (Screw vent, Paragon) } & 8 & 29 & 2 & 93.1 \\
\hline & & & 10 & 45 & 4 & 91.1 \\
\hline & & & 13 & 28 & 0 & 100 \\
\hline & & & 16 & 15 & 0 & 100 \\
\hline Deporter et al. 2001 [18] & Sintered porous & Endopore (Innova Corp) & 7 & 14 & 0 & 100 \\
\hline \multirow[t]{3}{*}{ Schincaglia et al. 2008 [17] } & \multirow[t]{3}{*}{ Ti-unite } & \multirow[t]{3}{*}{ Mark III WP (Nobel Biocare) } & 8.5 & 5 & 0 & 100 \\
\hline & & & 10 & 5 & 0 & 100 \\
\hline & & & 11.5 & 5 & 0 & 100 \\
\hline
\end{tabular}

retrospective, and 1 study that did not receive a clarification from the author.

\section{Data extraction}

One researcher (MT) extracted the data, and a second researcher (DPD) independently checked the data extraction for accuracy and completeness. The disagreements were resolved by discussion. The data extraction form was pilot tested on a representative sample before applying it to the selected articles.

\section{Statistical analysis}

The forest plot was used to determine pooled widediameter implant survival rate of the selected studies. The funnel plot was used to determine the possibility of publication bias of the selected studies. Heterogeneity of the data was analyzed to determine if the data from the selected studies can be analyzed and if the random effects model can be used in the meta-analysis. In addition, a meta-regression (type III test of fixed effects) was used to evaluate the effects of location, length, and surface on the implant survival.

\section{Results}

Of the six studies selected, three evaluated surfacetreated implants and three machined implants (Table 1).
The included studies all used similar criteria for implant survival, which was defined as the absence of mobility, pain, and radiolucent lesions. The implant survival was based on the percentage of implants evaluated, and the implant lengths in the studies range from 6 to $16 \mathrm{~mm}$ (Tables 2 and 3). The number of patients receiving wide implants was not specified in three studies which also evaluated other diameter implants [13-15]. Only data on the wide-diameter implants in those studies were included in the meta-analysis. Three studies evaluated only wide-diameter implants. The number of patients evaluated in these studies was as follows: Khayat et al. [13] studied 71 patients, Polizzi et al. [16] studied 34 patients, and Schincaglia et al. [17] studied 15 patients. Schincaglia et al.'s study was a randomized controlled trial evaluating immediate-loading versus delay-loading of wide-diameter implants; only data of the control group that was not immediately loaded was included in the meta-analysis. The mean patient follow-up of the six studies ranged from 1 to 8 years. The location of the implants placed in the selected studies (Table 4) was as follows: two studies evaluated implants placed in the posterior mandible $[17,18]$, one study in the edentulous mandible [14], and three studies in various areas of the maxilla and mandible $[13,15,16]$.

The forest plot (Fig. 2) showed a pooled wide implant survival rate of $96.3 \%$ (Table 5). The funnel plot (Fig. 3)

Table 3 Wide machined implants

\begin{tabular}{|c|c|c|c|c|c|c|}
\hline Study & Implant surface & Implant type & Implant length & No. of implants & No. failed & $\%$ survived \\
\hline \multirow[t]{4}{*}{ Polizzi et al. 2000 [16] } & \multirow[t]{4}{*}{ Machined } & \multirow[t]{4}{*}{ Brånemark (Nobel Biocare) } & 7 & 2 & 0 & 100 \\
\hline & & & 8.5 & 8 & 1 & 87.5 \\
\hline & & & 10 & 15 & 1 & 93.3 \\
\hline & & & 11.5 & 13 & 1 & 92.3 \\
\hline Friberg et al. 2000 [14] & Machined & Brånemark (Nobel Biocare) & 6 & 13 & 0 & 100 \\
\hline \multirow[t]{5}{*}{ Tawil and Younan 2003 [15] } & \multirow[t]{5}{*}{ Machined } & \multirow[t]{5}{*}{ Brånemark (Nobel Biocare) } & 6 & 16 & 0 & 100 \\
\hline & & & 7 & 3 & 0 & 100 \\
\hline & & & 8 & 27 & 1 & 96.3 \\
\hline & & & 8.5 & 8 & 2 & 75.0 \\
\hline & & & 10 & 55 & 3 & 94.5 \\
\hline
\end{tabular}


Table 4 Implants used in the maxilla and mandible

\begin{tabular}{|c|c|c|c|c|c|c|}
\hline Study & Implant surface & Implant type & $\begin{array}{l}\text { No. of implants in } \\
\text { maxilla (no. failed) }\end{array}$ & $\begin{array}{l}\text { No. of implants in mandible } \\
\text { (no. failed) }\end{array}$ & $\begin{array}{l}\% \text { survived in } \\
\text { maxilla }\end{array}$ & $\begin{array}{l}\% \text { survived in } \\
\text { mandible }\end{array}$ \\
\hline $\begin{array}{l}\text { Khayat et al. } \\
2001 \text { [13] }\end{array}$ & $\begin{array}{l}\text { Acid-etched, } \\
\text { uncoated }\end{array}$ & $\begin{array}{l}\text { Zimmer (Screw vent, } \\
\text { Paragon) }\end{array}$ & $49(2)$ & $62(4)$ & 95.9 & 93.5 \\
\hline $\begin{array}{l}\text { Deporter et al. } \\
2001 \text { [18] }\end{array}$ & Sintered porous & Endopore (Innova Corp) & 0 & $14(0)$ & - & 100 \\
\hline $\begin{array}{l}\text { Schincaglia et al. } \\
2008 \text { [17] }\end{array}$ & Ti-Unite & Mark III WP (Nobel Biocare) & 0 & $15(0)$ & - & 100 \\
\hline $\begin{array}{l}\text { Polizzi et al. } \\
2000[16]\end{array}$ & Machined & Brånemark (Nobel Biocare) & $4(0)$ & $34(3)$ & 100 & 91.2 \\
\hline $\begin{array}{l}\text { Friberg et al. } \\
2000[14]\end{array}$ & Machined & Brånemark (Nobel Biocare) & 0 & $13(0)$ & - & 100 \\
\hline $\begin{array}{l}\text { Tawil and Younan } \\
2003 \text { [15] }\end{array}$ & Machined & Brånemark (Nobel Biocare) & $22(2)$ & $87(4)$ & 90.9 & 95.4 \\
\hline
\end{tabular}

was analyzed for publication bias. No publication bias was found in the selected studies. The meta-analysis heterogeneity statistics were shown in Table 6 . The Q statistic was a measure of the total variance of the studies and along with the p-value showed that the studies do not differ significantly from the mean effect. The $\mathrm{I}^{2}$ statistic along with the $95 \%$ uncertainty interval measured the degree of inconsistency among the studies and showed no inconsistencies among the studies. $\tau^{2}$ was a measure of the between study variance and was defined as 0 if the $Q$ value was less than the expected variance (Number of studies -1). The results showed no significant heterogeneity among the included studies. Within the meta-analysis using a random effects model, a metaregression showed that the fixed effects of location, length and surface did not have a significant effect $(P>0.05)$ on survival (Table 7$)$.

\section{Discussion}

The present meta-analysis was limited to prospective clinical studies and utilized a rigorous inclusion and exclusion criteria. Studies included in the analysis were limited to cases in which implants placed in sites with adequate bone volume without grafting. Implants were placed in healed sites and loaded after at least 1-3 months of healing. All studies had at least 1-year follow-up. Patients were required to have adequate health to undergo implant surgery. Controlled medical conditions and smoking status were not excluded. Excluded were studies where implants were placed in sites that were initially deemed to have adequate bone; however, at the time of implant surgery, required the use of bone graft. Data from these studies could not be analyzed due to unclear documentation of which implants were grafted, thus preventing separation of the data for the analysis $[19,20]$. The data from some

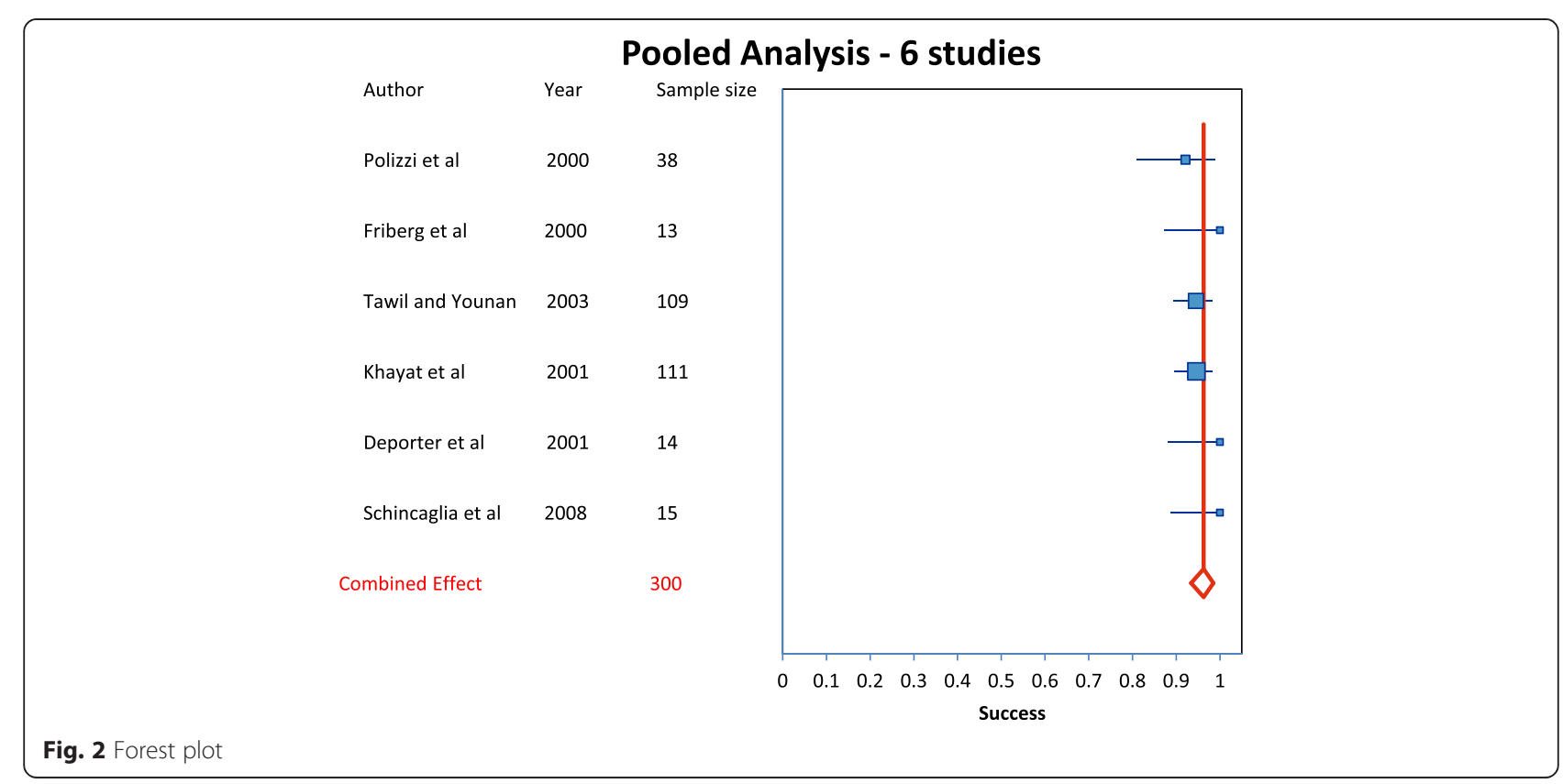


Table 5 Meta-analysis implant data-pooled analysis

\begin{tabular}{llllll}
\hline Authors & Number & Success & ci- & ci+ & Weight (\%) \\
\hline Polizzi et al. [16] & 38 & 0.921 & 0.810 & 0.990 & 12.71 \\
Friberg et al. [14] & 13 & 1.000 & 0.872 & 1.000 & 4.46 \\
Tawil and Younan [15] & 109 & 0.945 & 0.893 & 0.981 & 36.14 \\
Khayat et al. [13] & 111 & 0.946 & 0.895 & 0.982 & 36.80 \\
Deporter et al. [18] & 14 & 1.000 & 0.881 & 1.000 & 4.79 \\
Schincaglia et al. [17] & 15 & 1.000 & 0.888 & 1.000 & 5.12 \\
& 300 & 0.963 & 0.934 & 0.985 & 100 \\
\hline
\end{tabular}

of the survival studies were not able to be analyzed due to the lack of a clear description of implant length. The exclusion of these studies along with the rigorous inclusion criteria limited our meta-analysis to six studies. These six studies were well-documented with clear data on implant length, surface, and location.

The overall survival rate of wide-diameter implants based on the pooled data of the included six studies was $96.3 \%$, and this was within the reported range of widediameter [21] and regular-diameter [22] implant survival rates. Machined implants functionally integrate with the surrounding bone via a macroscopic interlock of the implant threads with the bone. Surface treatment of the machined threads increases the effectiveness of the interlock resulting in an improved bone-to-implant interface [23, 24]. However, our meta-analysis found no significant difference between the implant survivals of machined compared to surface-treated wide-diameter implants. Similarly, Al-Nawas et al. [25] also reported no significant difference between machined and double-etched surfacetreated standard-diameter implant survival. Conversely,
Table 6 Heterogeneity statistics

\begin{tabular}{lll}
\hline$Q$ & $P$ & \\
2.7008 & 0.7460 & \\
$P^{2}$ & $\mathrm{Ci}-$ & $\mathrm{ci}+$ \\
$0.00 \%$ & $0.00 \%$ & $74.62 \%$ \\
$T^{2}$ & $\mathrm{Ci}-$ & $\mathrm{ci}+$ \\
0.0000 & 0.0000 & 0.0069 \\
\hline
\end{tabular}

Maló and Araújo Nobre [26] reported significantly more failures for machined compared to surface-treated narrow (3.3-mm diameter) implants. This suggests that the implant surface characteristics may have an impact on implant survival rate based on the implant diameter, and as the diameter of the implant is increased, as in the widediameter implant, this impact may not be statistically significant. It should be noted that stringent inclusion criteria were applied including non-grafted sites, controlled medical conditions, and adequate bone volume.

In the present meta-analysis, the location of widediameter implants did not impact survival. This was in agreement with Degidi et al. [27] whose study did not find a statistically significant difference in the survival of wide-diameter implants in varying bone densities in the maxilla and mandible. However, this was contrary to some studies $[16,28]$ that reported a lower widediameter implant survival in the posterior mandible compared to the maxilla. This was postulated to be due to the low marginal bone vascularity of the mandible $[29,30]$. And, this was also contrary to some other studies [31, 32], which reported a better outcome for immediately placed implants placed in the mandible because of better bone density and quality.

\section{Heterogeneity funnel plot - publication bias}

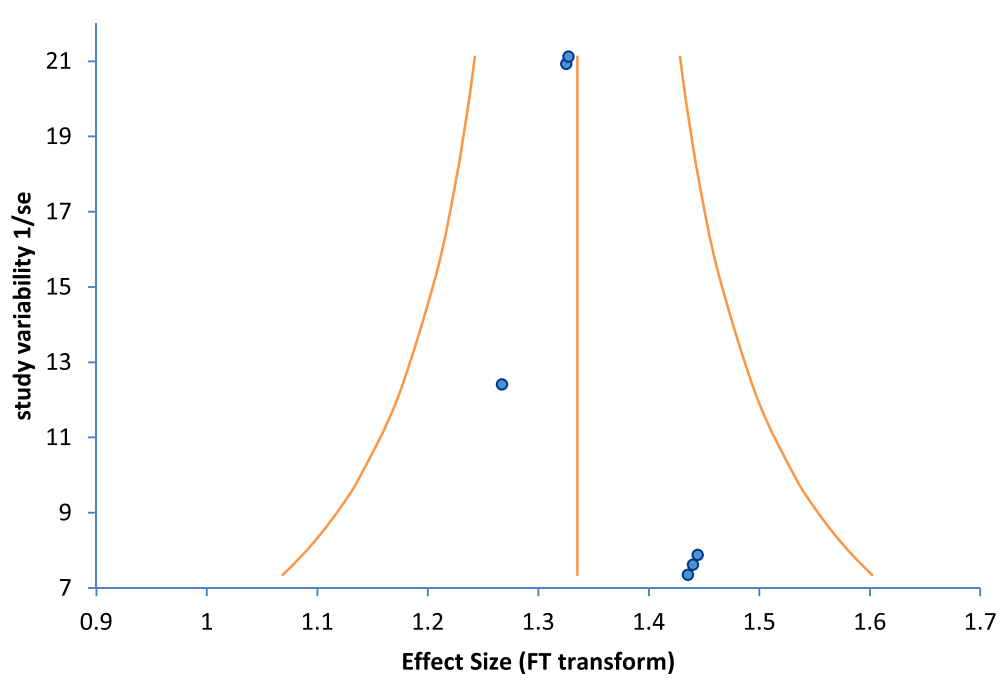

Fig. 3 Funnel plot 
Table 7 Meta-regression - effect of surface and lengths

\begin{tabular}{|c|c|c|c|c|}
\hline \multicolumn{5}{|c|}{ Type III tests of fixed effects } \\
\hline & Num & Den & & \\
\hline Effect & DF & DF & $F$ value & $P$ \\
\hline Surface & 1 & 11 & 0.84 & 0.3787 \\
\hline Length & 7 & 11 & 0.97 & 0.4951 \\
\hline Location & 1 & 11 & 0.00 & 0.9868 \\
\hline
\end{tabular}

Degree of free (DF) contributes to the determination of $P$ value

The various lengths of wide implants used in the six selected study ranged from 6 to $16 \mathrm{~mm}$, and the following implant lengths assessed in the meta-regression were 6,7 , $8,8.5,10,11.5,13$, and $16 \mathrm{~mm}$. Unlike our meta-analysis which focused solely on the wide-diameter implant, very few studies looked at the effects of different lengths on the survival rate specific to the wide-diameter implant. Most studies reported survival rates of the shorter implant lengths $(\leq 10 \mathrm{~mm})$ with varying diameter implants $(3.75,4$, 5 , and $6 \mathrm{~mm}$ ) [33]. Studies by Deporter et al. [18, 34] included different diameter implants and were not limited to only wide-diameter implants; these studies also found no significant effect of implant length on implant performance. Conversely, Olate et al. [35], who also included different diameter implants, observed the largest failure in their short implants compared to long or medium implants. However, Olate et al. evaluated 1649 implants retrospectively, 295 were wide-diameter implants (17.9\%), 1217 were regular-diameter (73.8\%), and 137 were narrow-diameter implants (8.3\%). Thus, their conclusion would pertain more to the regular-diameter implants which makes up the majority of implant evaluated in their study. This would seem to indicate that length may have an effect on regular-diameter implant survival, but this would require further investigation. Our meta-regression, which evaluated the prospective data of a total of 306 wide-diameter implants with lengths ranging from 6 to $16 \mathrm{~mm}$, concluded that wide-diameter implants ranging in length from 6 to $16 \mathrm{~mm}$ would not have any significant effect on the implant survival. It should be stressed that stringent inclusion criteria were applied for study selection, and hence, these results cannot be generalized to patients with medical or oral compromise.

\section{Conclusions}

This meta-analysis concluded that the location, length, and surface treatment of the wide-diameter implant do not significantly affect its survival. It is therefore suggested with caution that when the conditions of the implant site corresponds to the inclusion criteria used in our meta-analysis, choosing a wide implant in the posterior mandible or maxilla, where implant length may be limited by the nerve or the sinus, the use of a short implant regardless of the implant surface would not adversely affect its survival.

\section{Competing interests}

MT, MP, DPD, JPG, and JBS declare that they have no competing interests as to the content of the manuscript. SRJ holds common stock in the company DENTSPLY International, York, PA, USA, which markets various dental implant systems. Nevertheless, the author does not believe that the abovementioned disclosure presents any apparent conflict of interest with respect to the content and subject matter of this systematic review.

\section{Authors' contributions}

MT, MP, DPD, JBS, and SRJ contributed to the design of the study. MT, MP, and DPD contributed to study selection and data extraction. JPG formulated and performed the statistical analysis. All authors read, revised, and approved the final manuscript.

\section{Authors' information}

1. Miriam Ting, BDS, MS, Cert. Advanced Periodontology (USC), is in the Advance standing program at the Temple University Kornberg School of Dentistry.

2. Matthew Palermo, DMD, is an associate professor from the Department of Restorative Dentistry at the Temple University Kornberg School of Dentistry. 3. David P. Donatelli, DDS, is an assistant professor from the Department of Restorative Dentistry at Temple University Kornberg School of Dentistry. 4. John P. Gaughan, MS, PhD, MBA, is an associate professor (emeritus) and a statistician at the Temple University School of Medicine.

5. Jon B. Suzuki, DDS, PhD, MBA is a professor, chairman, and program director from the Department of Periodontology and Oral Implantology at the Temple University Kornberg School of Dentistry.

6. Steven R. Jefferies, DDS, MS, PhD, is a professor from the Department of Restorative Dentistry at the Temple University Kornberg School of Dentistry.

\section{Acknowledgements}

The meta-analysis by the statistician was funded by the Temple University Research Fund.

\section{Author details}

${ }^{1}$ Kornberg School of Dentistry, Temple University, 3223 North Broad Street, Philadelphia, PA 19140, USA. ${ }^{2}$ School of Medicine, Temple University, $3420 \mathrm{~N}$ Broad St, Philadelphia, PA 19140, USA.

Received: 29 June 2015 Accepted: 13 October 2015

Published online: 03 November 2015

\section{References}

1. Adell R, Lekholm U, Rockler B, Branemark PI. A 15-year study of osseointegrated implants in the treatment of the edentulous jaw. Int J Oral Surg. 1981;10(6):387-416.

2. Adell R, Eriksson B, Lekholm U, Branemark PI, Jemt T. Long-term follow-up study of osseointegrated implants in the treatment of totally edentulous jaws. Int J Oral Maxillofac Implants. 1990;5(4):347-59.

3. Albrektsson T. On long-term maintenance of the osseointegrated response. Australian Prosthodontic J Australian Prosthodontic Soc. 1993;7(Suppl):15-24.

4. Engquist $B$, Bergendal $T$, Kallus T, Linden U. A retrospective multicenter evaluation of osseointegrated implants supporting overdentures. Int J Oral Maxillofac Implants. 1988;3(2):129-34.

5. Jemt T, Lekholm U, Adell R. Osseointegrated implants in the treatment of partially edentulous patients: a preliminary study on 876 consecutively placed fixtures. Int J Oral Maxillofac Implants. 1989;4(3):211-7.

6. Albrektsson T. A multicenter report on osseointegrated oral implants. J Prosthet Dent. 1988;60(1):75-84.

7. Albrektsson T, Dahl E, Enbom L, Engevall S, Engquist B, Eriksson AR, et al. Osseointegrated oral implants: a Swedish multicenter study of 8139 consecutively inserted Nobelpharma implants. J Periodontol. 1988;59(5):287-96. doi:10.1902/jop.1988.59.5.287.

8. Langer $B$, Langer $L$, Herrmann I, Jorneus $L$. The wide fixture: a solution for special bone situations and a rescue for the compromised implant. Part 1. Int J Oral Maxillofac Implants. 1993;8(4):400-8. 
9. Graves SL, Jansen CE, Siddiqui AA, Beaty KD. Wide diameter implants: indications, considerations and preliminary results over a two-year period. Australian Prosthodontic J Australian Prosthodontic Soc. 1994;8:31-7.

10. Lazzara RJ. Criteria for implant selection: surgical and prosthetic considerations. Pract Periodontics Aesthet Dent. 1994;6(9):55-62. quiz 4.

11. Lee JH, Frias $V$, Lee KW, Wright RF. Effect of implant size and shape on implant success rates: a literature review. J Prosthet Dent. 2005;94(4):377-81. doi:10.1016/j.prosdent.2005.04.018.

12. Sullivan DY. Wide implants for wide teeth. Dental Econ Oral Hygiene. 1994;84(3):82-3.

13. Khayat PG, Hallage PG, Toledo RA. An investigation of 131 consecutively placed wide screw-vent implants. Int J Oral Maxillofac Implants. 2001;16(6):827-32.

14. Friberg B, Grondahl K, Lekholm U, Branemark PI. Long-term follow-up of severely atrophic edentulous mandibles reconstructed with short Branemark implants. Clin Implant Dent Relat Res. 2000;2(4):184-9.

15. Tawil G, Younan R. Clinical evaluation of short, machined-surface implants followed for 12 to 92 months. Int J Oral Maxillofac Implants. 2003;18(6):894-901.

16. Polizzi G, Rangert B, Lekholm U, Gualini F, Lindstrom H. Branemark System wide platform implants for single molar replacement: clinical evaluation of prospective and retrospective materials. Clin Implant Dent Relat Res. 2000;2(2):61-9.

17. Schincaglia GP, Marzola R, Giovanni GF, Chiara CS, Scotti R. Replacement of mandibular molars with single-unit restorations supported by wide-body implants: immediate versus delayed loading. A randomized controlled study. Int J Oral Maxillofac Implants. 2008;23(3):474-80.

18. Deporter D, Pilliar RM, Todescan R, Watson P, Pharoah M. Managing the posterior mandible of partially edentulous patients with short, porous-surfaced dental implants: early data from a clinical trial. Int J Oral Maxillofac Implants. 2001;16(5):653-8.

19. Attard NJ, Zarb GA. Implant prosthodontic management of partially edentulous patients missing posterior teeth: the Toronto experience. J Prosthet Dent. 2003;89(4):352-9. doi:10.1067/mpr.2003.91.

20. Tawil G, Mawla M, Gottlow J. Clinical and radiographic evaluation of the 5-mm diameter regular-platform Branemark fixture: 2- to 5-year follow-up. Clin Implant Dent Relat Res. 2002;4(1):16-26.

21. Davarpanah M, Martinez H, Kebir M, Etienne D, Tecucianu JF. Wide-diameter implants: new concepts. Int J Periodontics Restorative Dent. 2001;21(2):149-59.

22. Javed F, Romanos GE. Role of implant diameter on long-term survival of dental implants placed in posterior maxilla: a systematic review. Clin Oral Investig. 2015;19(1):1-10. doi:10.1007/s00784-014-1333-z.

23. Khang W, Feldman S, Hawley CE, Gunsolley J. A multi-center study comparing dual acid-etched and machined-surfaced implants in various bone qualities. J Periodontol. 2001;72(10):1384-90. doi:10.1902/jop.2001.72.10.1384.

24. Cochran DL. A comparison of endosseous dental implant surfaces. J Periodontol. 1999;70(12):1523-39. doi:10.1902/jop.1999.70.12.1523.

25. Al-Nawas B, Hangen U, Duschner H, Krummenauer F, Wagner W. Turned, machined versus double-etched dental implants in vivo. Clin Implant Dent Relat Res. 2007;9(2):71-8. doi:10.1111/j.1708-8208.2007.00030.x

26. Malo $\mathrm{P}$, de Araujo Nobre M. Implants (3.3 mm diameter) for the rehabilitation of edentulous posterior regions: a retrospective clinical study with up to 11 years of follow-up. Clin Implant Dent Relat Res. 2011;13(2):95-103. doi:10.1111/j.1708-8208.2009.00188.x.

27. Degidi M, Piattelli A, lezzi G, Carinci F. Wide-diameter implants: analysis of clinical outcome of 304 fixtures. J Periodontol. 2007;78(1):52-8. doi:10.1902/jop.2007.060139.

28. Ivanoff CJ, Grondahl K, Sennerby L, Bergstrom C, Lekholm U. Influence of variations in implant diameters: a 3- to 5-year retrospective clinical report. Int J Oral Maxillofac Implants. 1999;14(2):173-80.

29. von Wowern N. Variations in structure within the trabecular bone of the mandible. Scand J Dent Res. 1977;85(7):613-22

30. von Wowern N. Variations in bone mass within the cortices of the mandible. Scand J Dent Res. 1977;85(6):444-55.

31. Balshi TJ, Wolfinger GJ. Immediate loading of Branemark implants in edentulous mandibles: a preliminary report. Implant Dent. 1997;6(2):83-8.

32. Randow K, Ericsson I, Nilner K, Petersson A, Glantz PO. Immediate functional loading of Branemark dental implants. An 18-month clinical follow-up study. Clin Oral Implants Res. 1999;10(1):8-15.

33. Hagi D, Deporter DA, Pilliar RM, Arenovich T. A targeted review of study outcomes with short $(<$ or $=7 \mathrm{~mm}$ ) endosseous dental implants placed in partially edentulous patients. J Periodontol. 2004;75(6):798-804. doi:10.1902/jop.2004.75.6.798.

34. Deporter DA, Todescan R, Watson PA, Pharoah M, Pilliar RM, Tomlinson G. A prospective human clinical trial of Endopore dental implants in restoring the partially edentulous maxilla using fixed prostheses. Int J Oral Maxillofac Implants. 2001;16(4):527-36.

35. Olate S, Lyrio MC, de Moraes M, Mazzonetto R, Moreira RW. Influence of diameter and length of implant on early dental implant failure. J Oral Maxillofac Surg. 2010;68(2):414-9. doi:10.1016/j.joms.2009.10.002.

\section{Submit your manuscript to a SpringerOpen ${ }^{\odot}$ journal and benefit from:}

- Convenient online submission

- Rigorous peer review

- Immediate publication on acceptance

- Open access: articles freely available online

- High visibility within the field

- Retaining the copyright to your article

Submit your next manuscript at $>$ springeropen.com 